\title{
The Essence of Female Journalist Leadership in Conventional Media at Digital Era
}

\author{
Sunarto ${ }^{1}$, Nurul Hasfi ${ }^{2}$, Amida Yusriana $^{3}$, Luz Rimban $^{4}$, Heni Indrayani ${ }^{5}$ \\ \{amidayusriana88@gmail.com ${ }^{3}$ \} \\ Universitas Diponegoro, Indonesia ${ }^{1,2,3}$ \\ Ateneo de Manilla University, Philippines ${ }^{4}$ \\ Universitas Dian Nuswantoro, Indonesia ${ }^{5}$
}

\begin{abstract}
In era 4.0 that characterized by digital technology, the number of female journalist leader is still limited. This research aimed to describe the essence of female journalist leaders experience in doing their function. Standpoint theory in critical constructionism paradigm was applied to understand the phenomena. It assumed that male standpoint become the dominant perspective in the world. The viewpoint maintained the status quo and suppressed female standpoint. A critical phenomenology design was used to get data through in-depth interviewing virtually of several female journalists' leaders in conventional media companies in Indonesia. The result showed that the essence of female journalists' leadership in conventional media was to treat leadership as a tool to show the existence of themselves as child, mother, wife, worker, and individual. They used power as tool to empower themselves, female co-workers and female in general through editorial policy based on competence and media content that had gender sensitive to support political and economic interests of womenkind and company using optimally technology to adapt in the middle of pandemic and disruptive era. It seemed that feminist standpoint had not managed to overcome male standpoint in conventional media industries.
\end{abstract}

Keywords: Feminist Standpoint, Female Journalist Leadership

\section{Introduction}

The number of female journalists in Indonesia who position as leader in media industries are still limited. Male journalists are dominating the position. For instance, a local paper in Semarang has 4 males and 1 female leaders at editorial management [1] and a national paper in Jakarta has 14 males and 1 female leaders at editorial management [2]. It is just an example to show how domination of female journalist happens in conventional media.

Female journalists who run leadership in their media faced negative attitude from their male counterpart. They were downgraded as incompetence and easy to desperate. This condition did not support them to achieve organizational goals. There was a discrimination situation in certain degree that be faced by the female journalist to behave as a member or a leader in organizational media [3]. It seems women journalist leader meet organizational problems in interaction with their men counterparts.

This condition seems to show there is an unequal gender relation in the print and electronic media. This phenomenon does not fit with Article 281 in Amendment of UUD 1945 that states everyone has a right to free of discrimination treatment based on anything and has a right to get a protection from any discriminative treatment. This value is also relevant with Convention on 
the Elimination of All Forms of Discrimination against Women of United Nations that be ratified by our government as a national law [4].

Meanwhile media industries recently face new technologies as the consequences of internet progression. This condition makes difficult economically for media to develop financially. Digital era gives negative impact for media industries when cannot adapt with new condition. It seems print media industries face a "sunset industry". In case of local media, all the leaders tried to develop new strategies to solve their economic problem [5]. This new era creates economic problems for media industries in Indonesia.

The problem arises from the condition: How do female journalists' leader of conventional media experience the digital era in their organizational media? What is the substance experience of female journalists' leader when doing their leadership? What is kind of editorial strategic that be created by female journalist leader to adapt in the digital era to solve their economical and organizational problem? What is the substance of experience of female journalist leader to handle new technologies in digital era? This article will focus on describing the essence of female journalists' leader in editorial management to run their leadership in digital era.

A standpoint theory was applied to understand the phenomena [6]. This theory assumed that our world was dominated by a dominant viewpoint namely male standpoint. This standpoint created anything in this world using male perspective. Language to label anything in the world was created in patriarchal symbolic. To be existence, female must absorb themselves in male symbol. Time by time, male keeps the dominant standpoint as a normal status quo. People who behave outside the perspective will be labeled as deviant. So, the sexual division of labor, unpaid work in home, reproduction, the lack of power, and others are the implications of praxis the standpoint in this world. All the implication makes female in inferior position.

Many researches in many organizations that involved female as leader that be done before was supported the assumption [7-15]. Still many females did not have opportunity to position in top management because of traditional reason that place female in domestic area in home.

\section{Methodology}

To answer the problem, this research used a critical constructionism paradigm to guide all the research processes in qualitative approach $[16,17]$. A critical phenomenology research design $[18,19]$ was applied to get data from female journalist leaders as key informants in their position as Editor in Chief (Solo Pos Daily), Deputy Editor in Chief (Jawa Pos Daily), Senior Editor (Kompas Daily), and Editor (Solo Pos Daily). All the participants were selected purposively. Data was analyzed using phenomenology procedures.

\section{Results and Discussion}

The result showed that the essence of becoming leader in conventional media at digital era for all the female journalists related with treating leadership as a tool to show the existence of themselves as child, mother, wife, worker, and individual. They used power as tool to empower themselves, female co-workers and female in general through editorial policy based on competency and media content that contained gender sensitive to support political and economic interests of womenkind and company using optimally technology to adapt in the middle of pandemic and disruptive era. 


\subsection{Female Journalist Existence: Rational Self?}

The existence of being female seemed to be essential for participants. They treated leadership not as the end of their professional activities. Leadership was just a tool to get something important for their life and organization.

According to a participant, she ever refused several times to be positioned in editorial management functions. Firstly, she refused to be a Political Editor because it would create a conflict of interest between her position and her father position in government. Secondly, the same reason also she used to refuse a Chief Editor position when offered to her. Thirdly, she refused to be a Deputy Chief Editor because she had a baby. As a mother, she had to nurture her baby to grow well. The working rhythm of media would damage it. So, she refused the position. The same reason also she used to resign from Technological Editor position. Finally, she took position in editorial management such as Deputy Chief Editor and Chief Editor because she had no all the reason. Her father passed away and her children were being adult so they could manage themselves. Being a leader was not her vision. It was beyond her imagination. "I just live my life," said the Senior Editor of a national paper in Indonesia.

Other participant refused management position because of her existence as a wife. According to a participant as Deputy Chief Editor at her paper, when there were changing of position of Chief Editor, she was assigned to place the position. She refused it because she had to take care of her husband that being sick seriously. She might take care of him until he passed away. "It is not a mistake decision," said her convincingly.

Being existence also showed by other participant when divorced with her spouse to maintain her occupation as a journalist. She divorced her husband because there was different vision about family. According to the participant, her husband did not understand her occupation. He did not support her career. She divorced when being an Editor. She often went back home late since took the position. Her husband did not agree with that. She thought there was no same vision anymore between her and her husband. "I am having a principle if he is not happy, I am also not happy. So, I am divorcing him," said the participant as Chief Editor at her paper at local city in Central Java.

The experience of female journalist leader about their existence as female to keep their individual self is becoming something relevant with phenomenology assumption about the ways in which we relate to the world and its beings [20]. As a phenomenon, what participants did is to show how world appears or presents itself to us in their experience. Becoming leader in their media was not important as becoming themselves. They know what they did. It was not emotional consideration but rational for them. They maintained their individual self as important matter in their life.

It seems when the participant becomes rational being, they transform themselves to be male being that characterized as rational subject. This idea is supported in standpoint theory [21]. It assumes that the vision of the ruling group structures the material relations in which all groups are forced to participate. In our case, the vision of female journalist leader is influenced by male's vision. One of the visions relates to rational being.

\subsection{Female Journalist Leadership: Competence for All!}

According to Rosener, style leadership of female leader focuses more on sharing of power and information [22]. This style closes to democratic style of leadership or encourage the heart model in Herrick's term [23]. In this model, woman leader more often interacts with her 
subordinates, pushes them to participate and shows to them how to achieve personal goals together with organizational goals. How did participants perform their leadership style?

Leadership style of participants were characterized by their effort to increase knowledge related with their position. It was like a participant experience when assigned as an Editor of weekly edition. According to her, when she had a position as an Editor of weekly edition, her paper had a rubric of fashion. When her journalist who hold the rubric died, she had to continue it. However, her education background was agronomic. She knows nothing about fashion matters. So, she had to learn much more about it. It was not like recent condition where internet might support any information. She had to learn by herself by looking for the information in many ways such as going to library, book shop and asking her colleagues to buy it when going abroad. She did that because it was her responsibility to make the rubric still existed in her paper. "In the future, my skill in fashion inspires many young journalists to write in my style using fashion as part of criticism to dominant side," explained the participant.

Besides, the leadership style of participants also concerned to their subordinate's achievement. They offered same opportunity for employees to develop their skill and to position in management function. It was said by a participant that in every editorial meeting, she always gave same opportunity to female journalists to express their opinion. She encouraged them to voice their viewpoint about certain issue. She also gave same opportunity for them to position in management function. "It will depend on their capabilities to get the position," said the participant.

Other stated that competency was important to use to give certain assignment. She used competence to assign her subordinate. If there was a female journalist who know much about criminal issues, for instance, having skill to approach police officers, she would give her the assignment. "It is okay for me. It is professional job so seeing competency is important," said the informant.

The experience also be done by other informant who be assigned by her leader to get criminal news for years when she became a journalist at first time. "After being a journalist for a year, I am assigned to criminal beat for two years," explained the informant about her experience to coverage criminal issues.

Other participant emphasized on partnership relations with her subordinates. According to her, she tried to be a loyal and humble leader to her staff. She asked them to eat outside together or getting selfie. She also prepared training session to all divisions. She could not become an authoritarian leader for them. She treated them as her partner in achieving organizational goals. She often offered them facilities. But she also asked for them the consequences of the facilities. "If they may fulfill the target, I let the facilities for them. However, when they fail to get the target, I pull out it from them," said the participant.

What be done by participants confirmed female leadership style that emphasized on encouraging subordinated to maximize their competence to achieve personal and organizational goals. What they did also indicate what Schwab said about leadership in era 4.0. It is an era when there are many disruptions happened that caused by the domination of information technology in our life. There are many innovations created by the technology. It will change many old habits to be new one.

According to Schwab [24], leaders in digital era should has contextual intelligent (thought), emotional intelligent (heart), motivational intelligent (soul), and physical intelligent (body). Contextual intelligent relates with how leaders understand and apply their knowledge. Emotional intelligent concerns with how leaders process and unity their thought and feel and connect it in themselves and others people. Motivational intelligent focuses on how leaders use objective, belief, and individual and collective virtues to influence change and act for communal 
advantage together. Physical intelligent concentrates on how leaders improve and keep health of themselves and their environment to be ready to use energy that be needed to transform personal and system. It seems the characteristics are applied by female journalists' leader. It happened when they increased their knowledge and skill to connect and to influence their environment.

\subsection{Feminist Standpoint: Male Standpoint?}

Feminist leadership involves a leader in process of dialogic education that assumes continuously interaction between leader with subordinates to create conducive working climate to cultivate personal happiness as an important basis to achieve organizational goals. Feminist leadership is an active form of leadership. It is a process where a leader is an arranger for others, responsible for activities or carrier of experience. This leadership style aims to keep a spirit of women movement and creates spiritual bonding among women [25]. What done by participants seems to reflect this kind of leadership.

It was like what a participant expressed. She tried to encourage herself and her colleagues to be sensitive gender in their daily activities when producing content to their paper. She developed certain policy to control the product become sensitive gender. When this idea came from her leader first time, it seemed just economical matter. They needed content that differed with usual product. In that time, their paper performed much of masculinism in its content. "It caused there is just little number of female readers to our paper. We need the content that reflect female interests," explained the participant.

Other participant got ideas to create female rubrics from her male leader. The reason was to get advertising related to female products. Economic matters seemed dominant behind ideas to perform female interests in her paper. According to the participant, her male mentor asked about difficulties their paper to get consumer good advertising. It seemed the paper too masculine. He asked her to create certain rubrics to fulfill female interests.

Economical interest is behind the ideas to create contain that fulfill female interests seems relevant with male leader of local papers in Java when creating strategy to serve their community [26]. It seems economic matters dominate the operation of media industries that labeled as male sites. Moreover, in digital era the conventional media industries are predicted will not be survive to face new media industries that be supported by information technology.

\section{Conclusion}

It seems that feminist standpoint has not managed to overcome male domination in conventional media industries at digital era when economic interests still dominate behind its policy and product. Female journalist's leader seems just to actuate male economic interests when producing policy and content to fulfill female interests. However, when female journalists have same opportunities to achieve editorial top management positions in conventional media industries there is an opportunity for them to influence and to change their environment to be sensitive gender

\section{References}


[2] Kompas. Organizational Structure. January 21: 6,11. (2020)

[3] Sunarto. "Maskulinisasi Pekerja Wanita dalam Industri Media". Jurnalisme Profesional dan Literasi Media: 280-295. (2014).

[4] Anonimous. Hak-hak Perempuan: Instrumen Hukum untuk Mewujudkan Keadilan Gender. (2004).

[5] Sunarto \& A. Nugroho. "Esensi Pengalaman Kepemimpinan Manajemen Media Lokal di Pulau Jawa." Research Report: 1-188. (2016).

[6] C. Krolokke \& A. Scott Sorensen. Gender Communication Theories \& Analyses: From Silence to Performance. (2006).

[7] T. Everbach. "The Culture of a Women-Led Newspaper: An Ethnographic Study of the Sarasota Herald-Tribune". Journalism and Mass Communication Quartley. 83 (3): 477-493. (2006).

[8] B.E. Dartiningsih \& D.M. Julijanti. "Kepemimpinan Perempuan dalam Birokrasi Pemerintahan di Kabupaten Bangkalan Madura". Kepemimpinan yang Berperspektif Gender: 59-65. (2009).

[9] Riauwati. "Kepemimpinan Berperspektif Gender pada Bidang Politik di Maluku Utara". Kepemimpinan yang Berperspektif Gender: 66-73. (2009).

[10] O. Jatiningsih. "The Glass Ceiling dalam Kepemimpinan Kepala Sekolah Perempuan di Tiga Jenjang Sekolah Negeri di Surabaya". Kepemimpinan yang Berperspektif Gender: 264-272. (2009).

[11] R.A, Beam \& D.T. Di Cicco. "When Women Run the Newsroom: Management Change, Gender, and the News". Journalism and Mass Communication Quartley. 87 (2): 393-411. (2010).

[12] T. Correa \& D. Harp. "Women Matter in Newsrooms: How Power and Critical Mass Relate to the Coverage of the HPV Vaccine". Journalism and Mass Communication Quartley. 88 (2): 301 319. (2011).

[13] S. Simon \& C.L. Hoyt. "Exploring the Effect of Media Images on Women's Leadership SelfPerceptions and Aspirations". Journal of Group Processes \& Intergroup Relations. 16 (2): 232 245. (2012).

[14] Y.Z. Volz \& F.L.F. Lee. "What Does It Take for Women Journalists to Gain Professional Recognition? Gender Disparities among Pulitzer Prize Winners, 1917-2010”. Journalism and Mass Communication Quartley. 90 (2): 248-266. (2010).

[15] G. Seshu. The Stories Women Journalists Tell: Women in Media in South Asia. A report from the South Asia Media Freedom and Solidarity Project (SAMSN). (2014).

[16] Y.S. Lincoln \& E.G. Guba. "Paradigmatic Controversies, Contradictions, and Emerging Confluences". Handbook of Qualitative Research (3rd ed): 191-216. (2005).

[17] R. Heiner. Social Problems: An Introduction to Critical Constructionism (2nd ed.). (2006).

[18] C. Moustakas. Phenomenology Research Method. (1994).

[19] J. Melancon. "Thinking Corporally, Socially, and Politically: Critical Phenomenological after Merleau-Ponty and Bourdieu. Bulletin d'analyse Phenomenologique. X (8). (2014).

[20] S.Heinamaa. "Simone de Beauvoiris Phenomenology of Sexual Difference". Hypatia. 14 (4); 114-132. (1999).

[21] R. West \& L.H. Turner. Introducing Communication Theory: Analysis and Applications (3rd ed.). (2007).

[22] T.K. Gamble \& M. Gamble. Communication Works (8th ed.). (2005).

[23] D.F. Herrick. Media Management In the Age of Giants: Business Dynamics of Journalism. (2003).

[24] K. Schwab. Revolusi Industri Keempat. (2019).

[25] M. Humm. The Dictionary of Feminist Theory (2nd ed.). (1989). 